\title{
The Constant Gardener? Two books on women's sexual fantasies
}

\section{Susan Quilliam}

Writer, Broadcaster, Consultant and Trainer, Cambridge, UK

\section{Correspondence to}

Ms Susan Quilliam;

Cambridge, UK; susan@susanquilliam.com; http://www.susanquilliam.com

Received 23 July 2014 Accepted 23 July 2014

\section{CrossMark}

To cite: Quilliam S. J Fam Plann Reprod Health Care 2014;40:303-305.

\section{BACKGROUND}

Over the years, I've regularly reviewed books for the Journal, but I've never made individual books the focus of a Consumer Correspondent article. I'm about to break the mould by writing about two books: one written recently, the other during the so-called 'sexual revolution'.

The more recent book is Garden of Desires by Emily Dubberley, published in 2013. The older book is My Secret Garden by Nancy Friday, first published in 1973, then reissued for its 40th anniversary. Both books not only explore the subject of women's sexual fantasies, but have as their foundation personal stories from over 400 contemporary women. Together - and my motivation for making both of them the subject of this article - is that the books form a diptych illustrating women's sexuality then and now.

\section{MY SECRET GARDEN}

Nancy Friday's book was pivotal in that it took sexual fantasy from deniability into social acceptance. Her prologue is a personal account of the challenges of writing the book in the face of society's repudiation, men's disapproval and individual women's guilt. Friday's first foray into the exploration of women's fantasies was to include them in a chapter in a novel she was writing; her publisher's abhorrence at the idea and his assumption that any woman who fantasised was a 'sexual freak' persuaded her to stop writing and consign the novel to a bottom drawer.

It took several further years for her to begin talking openly to others about fantasy, collecting first her friends' disclosures and then placing advertisements in the press to gather more first-person accounts. The huge number of such accounts, together with their authors' admissions of relief and gratitude for being able to confide in someone, convinced her of the value of the project, showing her that a book revealing the contents of the female 'secret garden' might both fascinate potential readers and be hugely permission-giving to women worldwide.

And so it proved. Friday's subsequent high sales and passionate fan mail spanning four decades validate the book's role in not only confirming but also reinforcing the central place that fantasy holds in most women's sex lives, and in reframing fantasy as a normal and often helpful aspect of female sexual activity.

\section{GARDEN OF DESIRES}

Dubberley's Garden of Desires, written almost exactly 40 years later, is a celebration of the earlier book and a homage to it in title, process and subject matter. It is also a step further on. It could never be as original and ground-breaking as Friday's work simply because it was not the first. But coming second has allowed it to be insightful about female fantasy in a very different way. It views the topic in the context of the huge social changes in sexual freedom, family planning, reproductive health and the place of women in society that have happened during and since the Seventies in many - though, we must remember, not all - parts of the world. And, it draws on the increasing knowledge and insight gained by researchers, academics, essayists and bloggers who have studied female fantasy during the intervening decades.

So Dubberley is not only able to parallel the themes of Friday's 1973 book with those of 2013, comparing, contrasting, counterpointing. She is also able to place the earlier book in the context of what followed, and add sociological commentary about the intervening years. A key example here is to compare the two prologues; while Friday's is a personally revealing account of her struggle to bring the issues into the open, Dubberley's is a 
politically passionate but factually based historical review of what happened after that struggle. [If any Journal reader needs a short but perfectly formed summary of the development of women's erotic freedom since the sexual revolution, they should turn to pages 11-30.]

\section{FANTASY THEN, FANTASY NOW}

So what is the 'compare, contrast, counterpoint' between the two books? The most crucial difference between the two books is the normalisation of fantasy. While Friday was clearly making an unusual and unpopular stand in her era and her society, Dubberley speaks to a readership so converted that she is driven to add a reassuring caveat on why readers shouldn't berate themselves if they do not fantasise!

But have female fantasies shifted or remained constant over the years? Some themes in both 'Gardens' are hardy perennials. Still hugely popular are voyeurism and exhibitionism; sex with forbidden or inappropriate partners; group sex; dominance and submission. Though Dubberley is keen to stress - as Friday does - that fantasy masochism and sadism rarely translate into a woman's need for such in real life.

There are, however, significant changes to the canon. Significantly reduced are sex with animals, and extremes of violence such as erotic evisceration, perhaps because of women's increased power in society or perhaps because violence against women is now so endemic that its daily reality intrudes too brutally on female fantasy. Conversely, substantially increased are fantasies of gender fluidity - being a man; having a penis; taking the male role in the sexual act; being lesbian even though one is predominantly straight; being straight even though one is predominantly lesbian - perhaps to reflect the current flexibility in both in gender definition and gender roles.

\section{WHY FANTASISE?}

What is also very different is the current depth of understanding of female fantasy when compared to 1973. Friday majored on the core theory that women's prime motivation for fantasy was to resolve their guilty desires in the face of society's disgust at any evidence of female desire and eroticism.

Dubberley, by contrast, draws on ensuing research to analyse at length and in depth the very differing potential motivations of each of her fantasy categories and subcategories. Her conclusion is that though the kind of guilt Friday identified is still a factor today, it is far less common, and less influential than the drives to pleasure, orgasmic achievement, relaxation, acceptance, control (or the ceding of it) and the enhancement of partner sex.

She also makes clear that contrary to what many of Friday's original critics claimed, sexual fantasies do not usually develop from an attempt to reconcile childhood abuse, nor as compensation for an inadequate partner. Fantasy is not a sign of damage, distress, deficiency or depravity, but a glorious foundation to women's erotic personalities.

\section{GENDER POLITICS}

An additional key difference between the two books is the gender politics that each has been obliged to address. Friday's political task was single and focused: to prove the fact that women do fantasise and that this is both normal and natural. This task was neither simple nor easy at the time she was writing, but she achieved it and in so doing has given today's women and their partners a level of sexual freedom and permission that previous generations had never enjoyed.

Dubberley's task may seem more straightforward women nowadays are at least theoretically equal and sexually liberated. But though female fantasy has largely been normalised, it can still be seen as less valid than 'real sex'. Though it is now often judged as a sign of erotic mastery, that in itself can induce performance pressure. And as Dubberley points out, women's sexuality per se is still subject to a raft of myths which mean that real women's stories of the kind she quotes can be dismissed as inaccurate or exaggerated. She enumerates ten such myths: a handy checklist for anyone working in the field to make sure that their assumptions about female sexuality are squeaky-clean (Box 1).

\section{WHY READ THE BOOKS?}

The latter point leads us logically on to my final, and key, question. Why should health professionals be in any way interested in women's sexual fantasies? However comprehensive our sexual history-taking, it is rare that a question-and-answer session will touch upon whether women patients have erotic daydreams, what those dreams are, or how those dreams affect health, well-being and partnership. And certainly

\section{Box 1 Garden of Desires lists ten myths about} women's sexuality; for each, think "not necessarily"

1 Women don't like sex

2 Women don't masturbate

3 Women have fewer sexual partners than men

4 Women want romance, men want sex

5 Sex is for procreation only

6 Women do not pay for sex

7 Women are less sexually 'deviant' than men

8 Sex is a sin

9 Sexual content is corrupting

10 The sexual revolution is over 
while in the privacy of our own homes reading the first-person stories in either book might fascinate or even arouse, any detailed perusal of such stories is unnecessary to our clinical efficacy.

But I would suggest that the insights given by these stories - or more particularly by the commentaries each author makes and within which the stories are set - do afford valuable insights into women's sexuality as it has developed over the past four decades.

For as women walk into our consulting rooms, they bring not only their current presented problem, but also a whole context of dreams, hopes, concerns and anxieties about sex. They also bring the inherited and transferred dreams, hopes, concerns and anxieties of their mothers, their grandmothers, their daughters, and of the society in which they live. Awareness of female sexual fantasy can surely give us deeper insight into this entire arena.

To treat our patients, we may not need to read either of these books. To understand our patients fully, we may need to read both.

\section{FURTHER INFORMATION}

- Garden of Desires: The Evolution of Women's Sexual Fantasies. Emily Dubberley. London, UK: Black Lace, 2013.

- My Secret Garden. Nancy Friday. New York, NY: Rosetta Books, 2013 (previous editions 1973, 2001).

Competing interests None.

Provenance and peer review Commissioned; internally peer reviewed. 